\title{
Performance Measurement and Management in Public Enter- prises in India: A Case Study of NTPC
}

\author{
Alok Kumar Chakrawal \\ Dr., Professor, Department of Commerce and Business Administration, India \\ Pratibha Goyal \\ Dr., Professor and Director, School of Business Studies, Punjab Agricultural University, India
}

\begin{abstract}
Purpose. The purpose of the study is to analyze the holistic performance of NTPC - A Maharatna Company by using balance scorecard to view the effectiveness of NTPC in attaining its core values and business objectives. NTPC has classified their objectives into business performance, financial performance, customer orientation, $\mathrm{R} \& \mathrm{D}$, performance management and therefore the four perspectives of balance scorecard were ideal to analyze performance measurement and management of NTPC
\end{abstract}

Research Methodology and Approach. The present research uses descriptive and analytical approach of measuring performance of NTPC by using four perspectives of Balance Scorecard namely- financial, customer, internal processes and innovation \& learning. The annual reports, financial analyses, financial websites and newspapers are used as a secondary data source to analyze the performance.

Findings. It was observed that NTPC has defined its objective statement with utmost clarity to enhance the performance with measurable goal. With the application of balance scorecard it was found that there is a positive association of companies overall objectives with that of its performance.

Implications. It would provide a holistic view of the overall performance outcome and an opportunity to increase qualitative and quantitative performance to create more synergy and alignment of strategies with performance management system.

Key words: performance measurement and management, Maharatna Companies, public sector enterprises, NTPC, balance scorecard.

\section{JEL Classification: H11.}

(C) The Authors, 2018. This article is published with open access at Sumy State University.

\section{Introduction}

Ever since India has opened up its economy to privatisation, liberalization \& globalization, there has been rapid institutionalisation of the public and private enterprise. The vibrant business environment with massive economic change has quickened the pace of economic growth. The shift of free market economy system demands stakeholder's growth, sustainability and creation of higher values to win over in this highly competitive and turbulent business environment.

Public sector units in India has always portrait itself as benchmark model of performance for sustainable development by taking up major industrial responsibility to uplift the society and simultaneously attaining their economic goal. Together with their primary contributions of providing industrial components, they have also provided employment opportunities to millions of Indians and have been the vital source of revenue to the government. Many of these industrial units and organisations have been operating since the last 4-5 decades.

Such organisation have great significance in Indian economy and to honour their contributions and socioeconomic assistance, the Government of India confers special status to some of these industrial organisation for their contribution in overall growth and prosperity of Indian economy. ${ }^{10}$ In Indian Vedic verses "Ratna" is denominated as treasured gems and precious stones. It is of great importance for the companies to be inducted into the list of "Ratnas" in the country, because it gave them a different status and level in the society and among the other private and public undertakings. But their significance is equalled to their being important in the country's economy. Public Sector Undertakings are broadly classified into three categories, Maharatna, Navratna and Miniratnas are supposed to stand in the hierarchical order where the Maharatna (Maha=Vast 
and Ratna $=$ Gemstone), the Navratna $(\mathrm{Nav}=\mathrm{Nine}$ and Ratna $=$ Gemstone) and the Miniratna $($ Mini $=$ Small and Ratna $=$ Gemstone). The classifications of these companies are made on the basis of their expansion and market value.

In 2009, the government established the Maharatna status, which raises a company's investment ceiling from Rs. 1,000 crores to Rs. 5,000 crores. The Maharatna firms can now decide on investments of up to 15 per cent of their net worth in a project. Under the Maharatna status, companies can incur an expenditure on purchasing new products or go for replacement without any monetary ceiling. The procedure of granting Maharatna status is to be initiated by concerned Administrative Ministries or Departments and the final decision is taken by inter-ministerial committee with initiative of the Department of Public Enterprises. The Board will be delegated the special Powers to manage the company by a restructured board for which the Department of Public Enterprises will lays down certain rules and direction.

In the year 2016-17, the public sector undertakings like NTPC Limited, Bharat Heavy Electricals Limited, Coal India Limited, GAIL (India) Limited, Indian Oil Corporation, Oil and Natural Gas Corporation and Steel Authority of India limited, were entitled with the Maharatna status and given the privilege to raise capital and expand its horizon. Majority of these PSU are leading with energy \& power sector. In 2016, India ranks on $3^{\text {rd }}$ position in electricity production with $1423(\mathrm{TW} \mathrm{h})$. The electricity consumption in Industry sector and domestic sector has increased at a much faster pace compared to other sectors during 2007-08 to 2016-17 with CAGR of $7.82 \%{ }^{1}$ The production of electricity has witnessed a growth of $4.72 \%$ and the CAGR has grown by $7.03 \%$ from FY10-FY $18 .{ }^{2}$ Such expansion requires huge capital base which can be met by raising fund in the capital market which calls for the investor's protection and wealth maximisation of stakeholders. It has therefore, become crucial to incorporate quality orientation in management of finances which highly depends on the quality of human resource and other strategic in a company. Therefore, its important to have effective performance management and performance measurement system. The key performance indicators are focused towards finances, customer and stakeholder's value creation, internal processes and quality management and innovation \& learning perspectives. These parameters were introduced by Kaplan and Norton in 1992 as Balance Score Card (BSC) Framework. Balance scorecard aims at creating a synergy with organisational goals and performance outcome and measurement. BSC is used as a central management tool to upgrade and enhance effective performance measurement system and strategic management process.

\subsection{Overview of NTPC}

NTPC was incorporated in 1947 with the objective to accelerate power generation in India and today it has become largest energy developer in India. It is one of the dominant power developers and has marked it presences in the entire value chain of the power generation business. It came up with initial public offering in October in 2004 with $5.25 \%$ of fresh issue and $5.25 \%$ of issue which was offered to Government of India (GOI) and became a listed company in November 2004 by having $89.5 \%$ of equity holding held by GOI. However, the shareholding was reduced to $84.5 \%$ in 2010 through further public offering and it held $75 \%$ shareholding in GOI by 2013 by divesting through OFS route. The present shareholding is drop down to $62.27 \%$ as on $31^{\text {st }}$ march 2018 and DIIa held $22.23 \% 11.52 \%$ are held with FIIs, $1.57 \%$ is with individuals/ HUFs, 1.98 is which Body corporate and insurance companies and $0.43 \%$ lies in the hand of others.

In 2009 NTPC was recognised world with by availing $1^{\text {st }}$ rand as an Independent Power Producer (IPP) in and $10^{\text {th }}$ in overall performance among energy trader in Asia by Platts Top Globle Energy Company Ranking Award held in Singapore in 2009. In the same year, it was ranked $9^{\text {th }}$ in the list of 1000 companies by business standard 'BS- 1000' listing of corporate in 2009. They were ranked on the first position and had acquired highest place in India's Biggest News Maker survey conducted by Business today.

It grew in volume and dynamics over a period of time and got recognised as MAHARATNA COMPANIES in May 2010, among the top four companies who were awarded such honourable status and was bestowed the honour by Shri Pranab Mukherji, Union Minister of Finance of being the most respected company in power sector in 2011 by Business World. In 2015, $2^{\text {nd }}$ Indian Public Sector Enterprise Award for Excellence were organised at New Delhi wherein NTPC bagged the award entitled "World Class Indian Maharatna PSE of the Year". NTPC was ranked 400th in the '2016, Forbes Global 2000' ranking of the World's biggest companies.

\footnotetext{
${ }^{1}$ Source: Ministry of Statistics - Energy Statistic Report 2018

${ }^{2}$ Www.ibef.org/industry/power-sector-india.apx （IST :12:00PM 27-6-2018)
} 
In 2017, NTPC received Business Standard 'Star PSU' award which was presented by Shri Arun Jaitley, Finance Minister, GOI. It has also been awarded Golden Peacock Award and Greentech Award for CSR as FICCI Apprciation Plaque in 2012. In all the company has received awards for its performance and have strive to create higher reputation and stakeholders' value.

NTPC became India's largest energy conglomerate through it venture in generating fossil fuels to generating electricity via hydro, nuclear and renewable energy sources. It has diversified its business to attain various corporate objectives and have set a benchmark in the field of power trading, training professionals in power sector, rural electrification, ash utilisation and coal mining as well as in consultancy.

\subsection{Research Methodology}

The research framework of the study comprises of research problem, objectives, data \& methodological framework, balance score card, implication and limitation of the study.

Title of the study. Performance Measurement and Management of Maharatna Companies- A Case Study of NTPC

\section{Review of literature}

Sur. D, Chokrabotty K. (2015) conducted a study on financial performance of BHEL, a maharatna Central public sector enterprise in India for analysing is performance consistency with regards to few selected financial dimension for a period of study i.e. 2004-2014. It was observed that oerformance of BHEL was best in the year 2010-11 and worst in 200alue 4-05.however, it reported uniformity in liquidity, profitiblity and efficicency in working capital and financial asset management and its value generating capabilities. It was observed that working capital management significantly contributed in enhancing value in generating capability in contrast to fixed asset management.

Gautum. A, Ashutoash. K. A (2017) conducted a study on performance management system in a Power sector PSU with special reference to T.H.D.C. India Limited with the aim to analyse change in performance appraisal system and its inheritent challenges. The researcher has used Task Based on SMART Goal \& Balance Score Card on KRAs by designing questionnaire as a research tool. The result revealed that $61 \%$ executive were satisfied with existing Performance Measurement System (PMS) and more than 50\% believed that it is serving the purpose of performance planning and catering to the training needs in the company. The researcher has linked PMS with Performance Related Pay (PRP) and observed that PRP has significant impact on performance management.

Anand, M., Sahay, B. S., \& Saha, S. (2005) has conducted a research of 53 companies of diverse industry by using prowess data base and have used questionnaire - survey based approach to analyze performance measurement practices and performance scorecard in these selected companies. It was observed that use of BSC by these company has helped them to identify areas for reducing cost and improvement in performance at bottomline. It was concluded that there is no change in the performance of the company with regards to its sectoral classification of the company.

Wang, C. N., Lin, L. C., \& Murugesan, D. (2013) has conducted a survey of 10 listed PSU to evaluate the performance of Indian energy industry under multiple different inputs and outputs criteria. The researcher has used "Slacks-based measure of super efficiency"(SBM model) of Data Envelopment Analysis (DEA) to conduct the study which has demonstrated that GAIL, CPCL, OIL are at the top 3 of ranking influences. The ranking of super SBM model shows the order of performance scores from ONGC in the top position followed by MRPL, IOCL, and GAIL. However, the outcome of Malmquist Productivity Index (MPI) scores revealed that there is no significant changes happening on Indian stock markets even with financial crisis in a broad context. The researcher made use of This integrated numerical study for providing a better "past-presentfuture" insights through performance evaluation in India energy industry.

Sharma, D. P., Nair, P. C., \& Balasubramanian, R. (2005) has conducted a study to analyze the performance of Indian power sector during its restructuring from 1991 to 2001. The researcher has used various performance indicator like technical efficiency, operational efficiency, financial condition, per capita electricity consumption, Plant load factor (PLF), power sector outlay and GDP contribution, commercial losses and cost recovery and evaluated the role of regulatory and performance of private and public sector units. It was concluded that the restructuring process did not had any significant impact in improving technical efficiency, financial position, reduction in losses or customer satisfaction. The researcher concluded that there is a need 
to redefine the objectives of the power sector by enhancing lessons from past experiences and pitfalls.

\section{Research Problem}

It aims at examining the performance management and performance measurement of NTPC - The Maharatna Companies by using Balance Scorecard as a performance measurement tool. The researcher has evaluated various performance measurement parameters by aligning them with the objectives of NTPCs. Balance score card strives to evaluate performance of NTPCs with four major perspectives, namely- finance, customer \& stakeholders, internal processes and innovation \& learning perspectives.

\section{Objectives of the study}

1. To find the association of various performance indicator of balance scorecard and the overall performance of NTPC - Maharatna Companies in the year 2016-17.

2. To analyse the extent to which NTPC - Maharatna Companies have complied to its corporate objectives by using four perspectives of balance scorecard.

\section{Data Source}

The annual reports of 2016-17, of the NTPC - The Maharatna Company, are taken as a data source. Various financial reports and statements are taken from financial data source websites like Money Control, NSE, BSE and others.

Table 1. Balance Scorecard of NTPC- The Maharatna Company

\begin{tabular}{|c|c|c|}
\hline & Strategic Objective & Lag / Outcome Measure \\
\hline \multirow{4}{*}{ 丞 } & $\begin{array}{l}\text { - To maintain and improve the financial } \\
\text { soundness of NTPC by prudent manage- } \\
\text { ment of the financial resources. }\end{array}$ & $\begin{array}{l}\text { - The foreign ratings by Fitch and S\&P are at par with sovereign ratings. } \\
\text { - INDIA RATINGS AND RESEARCH has give the issuer rating is IND AAA/Sta- } \\
\text { ble/IND A1+ since last } 5 \text { years } \wedge \\
\text { - Enjoys highest credit-rating assigned by CRISIL, ICRA and CARE } \\
\text { - Robust financials and systems } \\
\text { - Statistics of financial growth from } 2012-13 \text { to } 2016-17 \\
\checkmark \text { Revenue Growth from Rs.68,775.51crores to Rs. } 79,342.30 \text { crores * } \\
\checkmark \text { Total fixed asset from Rs. } 100,045.52 \text { crores to Rs. } 180,092.81 * \\
\checkmark \text { Total net worth from } 80,387.51 \text { crores to } 96,231.23 \text { crores* } \\
\checkmark \text { Price earning ration- } 9.30 \text { to } 12.30\end{array}$ \\
\hline & $\begin{array}{l}\text { To continuously strive to reduce the } \\
\text { cost of capital through prudent manage- } \\
\text { ment of deployed funds, leveraging op- } \\
\text { portunities in domestic and international } \\
\text { financial markets. }\end{array}$ & $\begin{array}{l}\text { - Full fixed cost recovery FY17: } 91.62 \% \text { as against FY16: } 91.94 \%{ }^{\wedge} \\
\text { - Debt coverage service ratio FY : } 1.55 \text { times to FY16:1.74 times * } \\
\text { - Interest coverage ratio has increased from FY16:5.94 to } 6.50 \text { FY17* } \\
\text { - Improved Net leverage (net debt/EBITDA) in FY17: } 4.95 \text { times then FY16: } 5.02 \\
\text { times }{ }^{\wedge} \\
\text { - Able to generate } 0.18 x \text { cash from its debt capital }{ }^{+}\end{array}$ \\
\hline & $\begin{array}{l}\text { - To promote innovative funding models } \\
\text { to support entry into new businesses and } \\
\text { sustain long term growth. }\end{array}$ & $\begin{array}{l}\text { - Currently, it uses cost plus return on equity model of } 15.5 \% \text { along with incentive for } \\
\text { better than normative operations } \\
\text { - Have adopted a low risk model } \\
\text { - Range of Net worth ratio is } 2.1 \text { to } 3.1^{*} \\
\text { - New project funding debt equity of } 70: 30 \text { through domestic and international borrow- } \\
\text { ing* }\end{array}$ \\
\hline & $\begin{array}{l}\text { To develop appropriate commercial } \\
\text { policies and processes which would en- } \\
\text { sure remunerative tariffs, balance capital } \\
\text { work-in-progress and minimize receiva- } \\
\text { bles }\end{array}$ & $\begin{array}{l}\text { - } 21.6 \% \text { share in all India \& } 13.3 \% \text { at standalone capacity level }{ }^{\wedge} \\
\text { - Increase in the commercial capacity by } 1420 \mathrm{MW} \\
\text { - The average tariff FY: } 17 \text { is Rs.3.26/kWh as against FY:16 Rs. } 3.18 / \mathrm{kWh} \\
\text { - Consultancy Division posted an income of Rs. } 132.72 \text { crore as against Rs. } 100.76 \text { crore } \\
\text { - The income from energy sales has increased by } 10 \% \\
\text { - Provisions for Tariff adjustments FY17: Rs. } 98.88 \text { crores as compared to FY16: } \\
\text { Rs. } 145.28 \text { crores } \\
\text { - Trade Receivables reduced by } 50 \% \text {, FY17- } 35.59 \text { as against FY16 } 71.18 \\
\text { - Capital work-in-progress increased by } 22 \% \text { - FY17 Rs.80,522.55crores against FY16 } \\
\text { Rs. } 66,205.59 \text { crores }\end{array}$ \\
\hline$\stackrel{\grave{\Xi}}{\stackrel{\Xi}{\Xi}}$ & $\begin{array}{l}\text { - To adapt business models and organisa- } \\
\text { tion structures to capture value which is } \\
\text { progressively shifting towards the cus- } \\
\text { tomers. } \\
\text { - To foster a collaborative style of work- } \\
\text { ing with customers, growing to be a pre- } \\
\text { ferred brand for supply of quality and re- } \\
\text { liable power. }\end{array}$ & $\begin{array}{l}\text { - Sound Corporate Governance and Bottom up approach for CSR } \\
\text { - } 100 \% \text { realisation of bill receivable } \\
\text { - High Collection Efficiency with Effective Rebate System: lessen debtor period of } 38 \\
\text { days in FY17 (FY16: } 40 \text { days) against predetermined } 60 \text { days^ } \\
\text { - LCs maintained at } 105 \% \text { on an average monthly billing } \\
\text { - Robust payment security mechanism with TRA between GOI \& RBI* } \\
\text { - } 19 \text { consumer grievance redressal camps * } \\
\text { - Effective feedback through Customer satisfaction index survey } \\
\text { - } 71 \text { training program under PMI* } \\
\text { - Effective CRM practices }\end{array}$ \\
\hline
\end{tabular}


Table 1 (cont.). Balance Scorecard of NTPC- The Maharatna Company

\begin{tabular}{|c|c|c|}
\hline & Strategic Objective & Lag / Outcome Measure \\
\hline & $\begin{array}{l}\text { - To expand the customer portfolio } \\
\text { through profitable diversification into } \\
\text { downstream business inter alia E-mobility } \\
\text { and direct supply }\end{array}$ & $\begin{array}{l}\text { - Expected to be } 130 \mathrm{GW} \text { company with } 600 \mathrm{BU} \text { by } 2032 \\
\text { - Targeting } 30 \% \text { of energy generation from Non- fossil fuels } \\
\text { - Diversifying } 25 \% \text { of share in ancillary services and } 10 \% \text { in E-mobility for manufactur- } \\
\text { ing of Electric Vehicles } \\
\text { - Cross Border Power Trading } \\
\text { - Expected to enter cement business for higher Ash Utilization. }\end{array}$ \\
\hline & $\begin{array}{l}>\text { To ensure sustainable power develop- } \\
\text { ment by ensuring minimal wastage across } \\
\text { operations. } \\
>\text { To lead the sector in the areas of reset- } \\
\text { tlement and rehabilitation and environ- } \\
\text { ment protection } \\
>\text { To actively contribute towards societal } \\
\text { development }\end{array}$ & $\begin{array}{l}\text { - "Going Higher on Generation, lowering GHG intensity" } \\
\text { - Spending } 12 \%-15 \% \text { project cost on various environment protection equipments such as } \\
\text { ESPs, LWTP,AWRS, ZLD, CEMS ,CHP, COC and other } \\
\text { - R\&R Plan includes Project Affected Persons (PAPs), Initial Community Development } \\
\text { (ICD) Plan, Socio-economic Survey (SES), Village Development Advisory Commit- } \\
\text { tee (VDAC), a Social Impact Evaluation, (SIE) and Need assessment Survey (NAS) } \\
\text { - CSR spending of Rs. } 277.81 \text { crores i.e. } 2.48 \% \text { of profits } \\
\text { - Revenue expenditure of Rs. } 35.33 \text { Crore on SD projects in 2016-17 and benefited } 400 \\
\text { villages, } 360 \text { schools, } 10 \text { lakh people }\end{array}$ \\
\hline 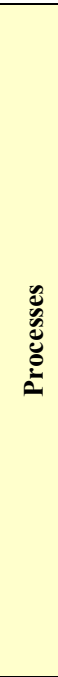 & $\begin{array}{l}>\text { To broad base the generation mix with } \\
\text { significant proportion of clean energy } \\
\text { sources } \\
>\text { To sustain NTPC's position as the } \\
\text { leading power generation company in the } \\
\text { world. } \\
>\text { To continuously strive for innovation } \\
\text { in reducing costs } \\
>\text { To continuously improve on project } \\
\text { execution time and cost in order to sus- } \\
\text { tain long term competitiveness. } \\
>\text { To assist in capacity creation of key } \\
\text { stakeholders. } \\
>\text { To undertake R\&D initiatives in sync } \\
\text { with the overall business } \\
>\text { To embed quality and safety in all sys- } \\
\text { tems and processes. }\end{array}$ & $\begin{array}{l}\text { - Allocated } 10 \text { coal blocks with estimated geological reserves of } \sim 7 \text { billion tonnes with es- } \\
\text { timated mining capacity of } 107 \text { million tonnes per annum and } 3 \text { more are proposed. } \\
\text { - Incorporation of NETRA for Efficiency Improvement } \\
\text { \& Cost Reduction, New \& Renewable Energy, } \\
\text { Climate Change \& Environmental Protection with ISO } 17025 \text { accredited } \\
\text { - During the FY17, } 17 \text { PLF of NTPC coal stations was } 78.59 \% \text { against all India PLF of } \\
59.88 \% \text { in FY:16 } \\
\text { - DC of coal station - FY17 was } 92.80 \% \text { as against } 92.29 \% \text { FY16 } \\
\text { - Reducing imported coal consumption by } 8 \% \text { of previous year } \\
\text { - Clean Development Mechanism promoting renewable energy generation } \\
\text { - Re-adjusting of NTPC's Fuel Generation Mix } \\
\text { - Effective Enterprise Resource Planning (ERP) Capacity building / Skill upgradation- } \\
\text { MOU with NSDC } \\
\text { - } 50.58 \% \text { viz. } 295.69 \text { lakh Tonnes for Ash Utilisation } \\
\text { - Higher Capacity creation then target, created } 13,395 \text { MW against targeted } 11,920 \text { MW } \\
\text { - Man MW ratio has improved to } 0.51 \text { in } 2016-17 \text { from } 0.54 \text { in } 2015-16 \\
\text { - Bagged Safety Innovation Award in } 2016 \\
\text { - Bagged Silver Winner in award category-Project Excellence in Mega-Sized Project } 2016 \\
\text { by International Project Management Association } \\
\text { - Implementation of ISO-14001,ISO 9001-2000, OHSAA-18001,5S,six sigma, Bench- } \\
\text { marking for attaining Zero Accident goal }\end{array}$ \\
\hline \multirow{5}{*}{$\begin{array}{l}\vec{y} \\
\Leftrightarrow \\
\end{array}$} & $\begin{array}{l}>\text { To pioneer the adoption of reliable, ef- } \\
\text { ficient and cost effective technologies } \\
>\text { To undertake R\&D initiatives in sync } \\
\text { with the overall business }\end{array}$ & $\begin{array}{l}\text { - Participation in 'Mission 2017- Development of Adv-USC technology' in collaboration } \\
\text { with BHEL and IGCAR would result into } 20 \% \text { less CO2 emission } \\
\text { - Around } 10-12 \text { projects are targeted towards technological development for energy gen- } \\
\text { eration and reduction in waste and pollutants. } \\
\text { - Adopted Technology for DeNOx } \\
\text { - Introduced Thermodynamically efficient technology } \\
\text { - Integration of solar thermal energy with conventional energy } \\
\text { - NETRA expanded horizon \& global collaborations } \\
\text { - IT enabled Project Monitoring Centres with web miles and PRIMS }\end{array}$ \\
\hline & $\begin{array}{l}>\text { To build and sustain a learning organi- } \\
\text { zation of competent world-class profes- } \\
\text { sionals. }\end{array}$ & $\begin{array}{l}\text { - } 3 \text { NTPC Station ranked top amongst other stations in the country in } 2017-18 \\
\text { - The learning activities comprises of infrastructure that includes Power Management In- } \\
\text { stitute(PMI), Employee Development Centers(EDCs), six Regional Learning Institutes } \\
\text { (RLIs) } \\
\text { - Participation of } 8096 \text { professionals in } 387 \text { programs organised by PMI } \\
\text { - Foundation of NTPC School of Business in } 2015 \\
\text { - Associated with } 26 \mathrm{IITs}, 1831 \text { new seats and benefited } 29109 \text { students, organised } 49559 \\
\text { Mandays trainings }\end{array}$ \\
\hline & $\begin{array}{l}\text { To align individual and organizational } \\
\text { needs and develop business leaders by } \\
\text { implementing a career development sys- } \\
\text { tem. }\end{array}$ & $\begin{array}{l}\text { - Implement best practices in performance measurement and management } \\
\text { - Cross functional teams and various committees } \\
\text { - Align employees to objectives } \\
\text { - Conducted } 11 \text { preventive vigillence workshop with } 477 \text { employees participation }\end{array}$ \\
\hline & $\begin{array}{l}>\text { To motivate and empower employees } \\
\text { for achieving strategic objectives. }\end{array}$ & $\begin{array}{l}\text { - Increased employees benefit cost- FY17-Rs. } 56989.17 \text { crores from FY16- Rs.52956.73 } \\
\text { crores } \\
\text { - Provides stock option plan }\end{array}$ \\
\hline & $\begin{array}{l}\text { - To build a lean organization with di- } \\
\text { verse skills and high ability to adapt to } \\
\text { change }\end{array}$ & $\begin{array}{l}\text { - During 2016-17, PMI conducted almost } 387 \\
\text { - training programmes covering nearly } 8,096 \\
\text { - professionals, logging a total of approximately } \\
\text { - } 30,898 \text { training mandays. }\end{array}$ \\
\hline
\end{tabular}


Findings and Analysis

Table 2. Financial Perspective

\begin{tabular}{|c|c|c|c|c|c|c|}
\hline Financial indicator & $\begin{array}{c}\text { Mar } \\
2017-18\end{array}$ & $\begin{array}{c}\text { Mar } \\
2016-17\end{array}$ & $\begin{array}{c}\text { Mar } \\
2015-16\end{array}$ & $\begin{array}{c}\text { Mar } \\
2014-15\end{array}$ & $\begin{array}{c}\text { Mar } \\
2013-14\end{array}$ & $\begin{array}{l}\text { Performance } \\
\text { Indicator }\end{array}$ \\
\hline Enterprise Value (Cr.) & & $234,242.76$ & $188,177.92$ & $187,150.37$ & $145,998.67$ & D \\
\hline Net worth & & $96,231.23$ & $88,782.00$ & $81,657.35$ & $85,815.32$ & \\
\hline Total Revenue & & $79,342.30$ & $72,009.16$ & $75,362.37$ & $74,707.82$ & \\
\hline Net Profit/(Loss) For the Period & $10,343.17$ & $9,385.26$ & $10,769.60$ & $10,290.86$ & $10,974.74$ & 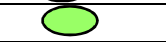 \\
\hline Net Profit Margin (\%) & & 11.99 & 15.20 & 14.04 & 15.23 & \\
\hline Return on Assets (\%) & & 3.96 & 5.00 & 5.22 & 6.11 & 2 \\
\hline Total Debt/Equity (X) & 1.14 & 1.08 & 1.01 & 1.03 & 0.78 & D \\
\hline Asset Turnover Ratio (\%) & & 33.08 & 32.92 & 37.16 & 40.10 & 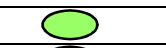 \\
\hline Return on capital employed (\%) & & 13.39 & 14.56 & 13.68 & 14.37 & $\sum$ \\
\hline Return on net worth (\%) & & 17.68 & 19.56 & 16.78 & 17.72 & \\
\hline Current Ratio (X) & & 0.79 & 0.94 & 1.29 & 1.58 & \\
\hline Inventory Turnover Ratio (X) & & 12.03 & 9.80 & 9.83 & 13.40 & S \\
\hline Equity Dividend Rate (\%) & 51.20 & 47.80 & -- & 25.00 & 57.50 & \\
\hline Basic EPS & 11.87 & 11.38 & 13.06 & 12.48 & 13.31 & \\
\hline Diluted EPS & 11.87 & 11.38 & 13.06 & 12.48 & 13.31 & 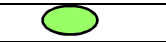 \\
\hline Dividend / Share(Rs.) & & 4.78 & 3.35 & 2.50 & 5.75 & D \\
\hline Revenue from Operations/Share (Rs.) & & 94.93 & 85.51 & 88.83 & 87.34 & \\
\hline Earnings Retention Ratio (\%) & & 77.07 & 73.04 & 79.97 & 56.80 & 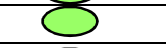 \\
\hline EV/Net Operating Revenue (X) & & 2.99 & 2.67 & 2.56 & 2.03 & S \\
\hline Price/BV (X) & & 1.42 & 1.20 & 1.49 & 1.15 & \\
\hline Price/Net Operating Revenue & & 1.75 & 1.51 & 1.66 & 1.37 & 5 \\
\hline Earnings Yield & & 0.07 & 0.10 & 0.08 & 0.11 & \\
\hline EV/EBITDA (X) & & 10.48 & 10.17 & 10.47 & 7.13 & \\
\hline MarketCap/Net Operating Revenue (X) & & 1.75 & 1.51 & 1.66 & 1.37 & S \\
\hline P/E Ratio & & 12.85 & & & & \\
\hline \multicolumn{2}{|c|}{ UNFAVOURABLE } & \multicolumn{4}{|c|}{ FAVOURABLE } & \\
\hline
\end{tabular}

Source: $41^{\text {st }}$ Annual report of NTPC 2016-17 and www.moneycontrol.com

Looking into the financial health of NTPC, it can be observed that company has acquired sound financial base and is growing consistently in terms of its capital, enterprise value, networth and total revenue. The major concern lies with its debt-equity ratio and current ratio. It can be observed that company has cling into debt financing and it excessively prefers to finance its existing short term requirement and new projects with borrowed capital. There is negative shift in the debt equity ratio which is gradually improving from previous year but it has improved D/E ratio in first quarter of FY 2018. Although, the debt coverage ratio is has reduced in FY17 - 1.55 as compared to FY16 - 1.74, the company is still above the desired debt coverage ratio i.e. 1 and is in the capacity to meet the financial obligation. The interest coverage ratio is FY17 - 6.50 which has increased from FY16- 5.94, indicating company's capacity to handle extra debt and being creditworthy in the eyes of lenders.

The current ratio for FY17 is 0.79 as against FY16 - 1.94, further declining from 1.58 in 2013-14. This reveals that company is constantly exceeding its current liability over its current asset showing growing liquid crunch situation over period of time. However, the median of current ratio in past 13 years is quite satisfactory i.e. 1.95 which falls into the current ratio ranging from 3.05 to $0.79 .{ }^{1}$ The company has observed higher inventory ratio that indicates growing sales of NTPC in domestic and international level. The asset turnover ratio has increased from FY16: 32.92 to FY17:33.08 and PBDIT margin has increased favourably to 28.55 as against 26.24 in the previous years. There is steep in Net Profit(NP) margin in FY17: 11.99\% and Return on Asset(ROI) which is 3.94 as a result of decrease in profit in FY17: Rs.9385.26 crores as against Rs. 10769.60 crores in FY16. The drop in net profit could be the result of higher interest paid on debt because no negative change is observed in PBDIT margin, PBIT and PBT margin. However the company is expected to earn a net profit of Rs. 10.343.17 in FY18. ${ }^{2}$

Earning and cash retention ratio has increased and slightly declined, indicating more reserves for expansion

\footnotetext{
${ }^{1}$ www.gurufocus.com/term/current-ratio/NTPZY/Current-Ratio/NTPC\%20Ltd

${ }^{2}$ www.m.moneycontrol.com/stock/NTP/financials/financials-ratio
} 
and innovation. The company has also notice positive change in Debtor Turnover ratio, Return on Long term fund ratio, Price earning ratio, Price/ Book value ratio, Price/ Net operating revenue, EV/EBITDA which shows sound financial condition of NTPC in terms of Enterprise Value(EV) and Market capitalisation value.

The company has robust financial systems \& framework, IT installation in each operative system, internal auditing and financial control system integrated with expertise financial organisation. The company availed various awards for its financial health, corporate governance and CSR practices. The company has got IND AAA and IND A1+rating by various credit rating agencies- national and international for Long-Term and Short-Term issues respectively.

Overall, NTPC is observing progressive financial growth and attaining company's goals of capacity creation to be worlds largest energy generator with diversified fuel- mix and innovative low emission technology usage. However there are scope for improvement in balancing Debt/Equity and maintaining liquidity in cash flow.

\section{Internal Business Perspective}

NTPC has signed a MOU with Union Power Ministry to generate 268 billion units of electricity during the fiscal year 2018-19 and this would generate 85,000 crores revenue from the operation.1 NTPC has exceed the target of capacity building by adding 13,395 MW capacity in 12th Plan (2012-2017) which was target to 11,920 MW in the Plan.

NTPCs is working towards attaining its goal of being country's largest green power producer and have therefore drafted a business plan of capacity addition of about 1,000 MW through renewable resources by 2017 wherein they have already commissioned 845 MW Solar PV Projects that are incorporated at stations at Andhra Pradesh, Madhya Pradesh and Rajasthan being the most crucial in its. The company has implemented an Energy Efficiency Projects (EEP) to promote energy conservation and climate change. By entering in the agreement with Energy Efficiency Services Ltd. (EESL), NTPC is working on Energy Audit of Buildings, Perform Achieve Trade (PAT) scheme work and standard \& leveling work of BEE, Consultancy work, implementing Bachat Lamp Yogana and Agricultural \& Municipal Pump replacement for various State Govts. NTPC has installed Ambient Air Quality Monitoring Systems (AAQMS) and became a pioneer in Environment monitoring by adopting NOx, SOx, CO, SPM \& RSPM analysers in 20 operating stations in the year 2009-10. It has taken a proactive approach of making all its power stations to operate with ZLD (Zero liquid discharge) progressively in phases.

The Growth strategy of NTPC approaches towards diversified fuel mix by becoming 130 GW company by 2032 and a $600 \mathrm{BU}$ company in terms of generation. The company is foster towards green energy creation and segmenting into ancillary services and storage and supply of electricity in E-mobility business.

The company operates with various committees has ensure attainment of the various objectives of the company and facilitates constant monitoring and review of performance in each of its division, segments and projects. The technical committee ISO and IEC is actively contributing in formulation and updating of power sector technical and quality standards/ guidelines, to serve the national as well as international community at large. The company has sound internal control mechanism which operates with Audit Committee and Management Controls Committee to ensure regular and exhaustive internal audits by the experienced Chartered Accountants firms by associating it with its Internal Audit Department. This helps the company to ensure regulatory and statutory compliance and provide highest level of corporate governance with a periodic review that tracks environmental changes in the business and promotes prompt decision making to eliminate risk and grab the opportunities. The Internal Control Framework system presents a written assessment of effectiveness of Company's internal control over financial reporting by the process owners to facilitate certification by CEO and CFO and enhances reliability of assertion.

NTPC believes in quality enhancement and quality management and therefore greater emphasis is made in training and development of the employees and ensures long term reliability and availability of its productive assets and investment. They use time tested systems and processes, maintain field laboratories at various construction sites and stay updated with the technologies to pursue manufacturing, erection and commissioning of various products/systems/ services. They maintain good connections and interactions with the major power 
equipment providers across the world and make use of feedback systems to ensure that standard performances and goals of the company are achieved with continuous upgradation and improvement. The company is dynamically engage in performance improvisation and has employed robust performance on all the parameters. This has brought sound quality management system in NTPC and secured the interest of various stakeholders of the company.

\section{Innovation, Learning \& Growth Perspective}

NTPC has a large number of employees that includes 1330 permanent Women Employees and 493 permanent Employees with Disabilities in its 22,124 employees including JV/ subsidiaries employees. NTPC has well acquitted force of talented employees who are inducted, developed and retained to meet the organisation objectives. The Performance Management System (PMS) of NTPC is like a benchmark that has been followed across the board.1 So far no complaint is being registered against NTPC regarding child labour, forced labour, involuntary labour, and sexual harassment. NTPC has been rated as most preferred place to work with its sound HR policy and safe working environment. Employees safety and security are one of the keen objective of the company and this matters are look upon by various committees like Risk Management Committee (RMC), Management Committee Meeting (MCM), ORTs, PRTs etc. It operates with four pillars in its HR system, namely- Competence building, Commitment building, Culture building and Systems building. The company has also have integrated Knowledge Management System and have adopted effective training infrastructure. The company also conducts Employee Satisfaction and Organisational Climate Surveys.

The employees benefit expense for the quarter ended on $31^{\text {st }}$ December, 2017 is higher by $4 \%{ }^{2}$ The employee's benefits expenses have risen from 3481.65 crores in FY 2015-16 to 4324.60 crores in FY 2016-17. NTPC has offered 2.74 crores equity share to is employees at a discounted price of Rs. 159.60 per scrip in august $2017 .{ }^{3}$ The company offered share to their prominent employees by selling $5 \%$ of stake held by the government. The company has benefited their employees by providing secured and unsecured loan and the amount including accrued interest comes to 252.52 and 97.81 crores respectively. NTPC provides various post employment benefit plans that includes employees provident fund, gratuity fund, retirement employees medical benefit fund and contribution pension trust.

The Man MW ratio has improved to 0.51 in $2016-17$ from 0.54 in $2015-16$. The rate of attribution is $0.93 \%$ and there is positive shift in the Man- MW ratio that is 0.51 as compared to 0.67 in 2012-13 demonstrating more efficient outcome then past years. The generation of energy per employees has improved and climb to 12.16 MUs (million units) as compared to 9.72 MUs in 2012-13. The value added per employee has increased from 1.27 crores in 2016 to 1.42 crores in 2017.

NTPC employees participate in various activities through Employee Voluntary Organization for Initiative in Community Empowerment (EVOICE). NTPC has been taking up CSR Activities in all the major sectors, in the vicinity of its operating stations, benefiting communities in more than 400 villages. NTPC during 201617 undertook activities in the neighbourhood area of stations addressing primarily the basic needs like primary education, community health, drinking water, sanitation, vocational training, women empowerment and village infrastructure like roads, community centre, solar street lights etc.

The company has adopted dynamic technological up gradation over a period of time which has resulted in to higher capacity, increased revenue, more safety and reduced cost and pollutants. Various collaborations and global initiative has created vibrant business environment that serves the need to distinct stakeholder and is creating higher utility and goodwill of the company at national as well as international level.

\section{Customers Perspectives}

NTPCs have stated their core values which includes customer focus and whereby they strive for expanding customer portfolio through profitable diversification by adopting a business model which operates in collaboration with the customer to ascertain values that are customer driven.

NTPC has a large customer base which mainly comprises of electricity utilities that are owned by the state

\footnotetext{
${ }^{1}$ Stated by Mr. R.C. Shrivastav in a featured article "NTPC Towards becoming an Employer of Choice"

${ }^{2}$ Reported by The Hindu Business Line on January 2018(www.hindubusinessline.com/news/ntpc-net-dips-4/article22613713.ece)

${ }^{3}$ Economics times www.economicstimes.indiatimes.com- $6^{\text {th }}$ Sept, 2017 (03.43 PM IST).
} 
government and private Discom operating in various states. The agreement of sales of electricity is made with the customer on the basis of long term Power Purchase Agreement(PPAs) and the allocation of power is made by Ministry of Power(MoP) as per the need of the customer that are stipulated by guidelines and policies.

The achievements of the company lies in $100 \%$ of its current bills realisation for supplying energy in the year 2016-17 and it has been doing this for $14^{\text {th }}$ consecutive years. With its Rebate Scheme which was introduced in 2017-18, majority of their customers made their payment within 60 days of billing and they have further maintained Letter of Credit (LCs) at 105\% of the average monthly billing. In order to be secured from any kind of defaults, the company has introduced robust payment security mechanism in the form of LCs that is backed by Tri-Partite Agreement (TPA) which is signed amongst Government of India(GOI) and Reserve Bank of India(RBI) through which recovery of amount is made directly by RBI.

Major end users of power can be broadly classified into industrial, agricultural, domestic and commercial

Consumers, representing $42 \%, 17 \%, 24 \%$ and $9 \%$ of power consumption units respectively in the year 201516. Traction \& Railways and others represented about $8 \%$ of power consumption.

To review the customer's satisfaction and avail their feedback, company has initiated Customer Relationship Management (CRM) and Customer Satisfaction Index (CSI). This enables the company to share its experiences, best practices, various innovations and achievements with the customer. Under the customer relationship management, the company provides various support services and organises various training programs to beneficiaries companies under its power management institute(PMI) at free of cost. In the year 2016-17 the company has organised 71 programs which included 134 participants from its various customer organisation and provides value to their customers. Some of these activities included providing various support services to the beneficiaries, which involves identifying potential areas of cooperation and sharing of each others' best practices. In the financial year 2016-17, a total of 61 such programmes have been conducted for the customers on the basis of requirement expressed by them. The customer satisfaction index (CSI) survey helps to understand the need and expectation of their customers and takes all possible actions by enhancing their feedbacks and suggestions. NTPC has organised 19 Customer Grievance Redressal Camps at Projects in which vendors concerns and suggestions were discussed and noted by using Social Medias like Facebook, Twitter \& LinkedIn. In last five years, no case is been filled by any of the stakeholder with regards to unfair trade practices, irresponsible advertising and / or anti-competitive behaviour.

\section{Conclusion}

The contribution of NTPC is around 30\% of Country's annual production of power generation. NTPC has showcased sound financial health and acquired huge power production capacity to attain its goal of sustainable and world's largest energy generator. It is widely expanding its capacity for generating renewable energy by discharging its responsibility by being environmental friendly and creating higher values for all its stakeholders. It was observed that NTPC has defined its objective statement with utmost clarity to enhance the performance with measurable goal. Overall, the outcome of balance score card has rated NTPC as progressive company with innovative learning practices and strong internal and financial management. The performance management system of NTPC is win-win approach and meets all the strategic goals. NTPC has optimist market view and has displayed benchmark in context to its quality orientation, innovation and HR development, safety and security, IT application in each operation and constantly strived for reduction in emission and cost.

With the application of balance scorecard it was found that there is a positive association of companies overall objectives with that of its performance. Hence, it can be concluded that Balance Score Card has displayed a significant performance of NTPC in all the four parameters and has been an efficiently performing under progressive management system.

\section{References}

1. Anand, M., Sahay, B. S., \& Saha, S. (2005). Balanced scorecard in Indian companies. Vikalpa, 30(2), 1126.

2. De Bruijn, H. (2002). Performance measurement in the public sector: strategies to cope with the risks of performance measurement. International Journal of Public Sector Management, 15(7), 578-594.

3. De Bruijn, H. (2003). Managing performance in the public sector. Routledge.

4. Heinrich, C. J. (2002). Outcomes-based performance management in the public sector: implications for government accountability and effectiveness. Public administration review, 62(6), 712-725. 
5. Kaplan, R. S., \& Norton, D. P. (1999). The balanced scorecard for public-sector organizations. Balanced Scorecard Report, 15(11), 1999.

6. Kaplan, R. S., \& Norton, D. P. (2001). Transforming the balanced scorecard from performance measurement to strategic management: Part I. Accounting horizons, 15(1), 87-104.

7. Kaplan, R. S., Robert, N. P. D. K. S., Davenport, T. H., Kaplan, R. S., \& Norton, D. P. (2001). The strategyfocused organization: How balanced scorecard companies thrive in the new business environment. Harvard Business Press.

8. Kaplan,R.S., \& Norton,D. P.(1999). The balance scorecard for public-sector organizations."

9. Sharma, D. P., Nair, P. C., \& Balasubramanian, R. (2005). Performance of Indian power sector during a decade under restructuring: a critique. Energy Policy, 33(4), 563-576.

10. Verbeeten, F. H. (2008). Performance management practices in public sector organizations: Impact on performance. Accounting, Auditing \& Accountability Journal, 21(3), 427-454.

11. Vine, E. (2005). An international survey of the energy service company (ESCO) industry. Energy Policy, 33(5), 691-704.

12. Wang, C. N., Lin, L. C., \& Murugesan, D. (2013). Analyzing PSU's performance: A case from ministry of petroleum and natural gas of India. Mathematical Problems in Engineering, 2013. 